\title{
A Minimum Budget for Current Acquisitions
}

\begin{abstract}
Since the ACRL "Standards for College Libraries" are at best a questionable guide in budget preparation, the writers attempted to arrive at a more objective formula for a basic budget for current acquisitions. The article proposes a minimum figure for books, based on an examination of reviews in seventy-one professional journals.
\end{abstract}

\begin{abstract}
F OR MANY YEARS library administrators and acquisitions librarians have been concerned about arriving at basic cost figures for book budgets. In preparing the budget the fiscal manager can find all kinds of advice about preparing the budget early, comparing his library with similar institutions (which are probably as inadequate as his own), considering the educational goals of the institution, etc. The administrator can find little guidance, however, on actual costs in the area of acquisitions.

The 1959 ACRL "Standards for College Libraries" skirt the central issues of collection size and book budget. The "standard" of 50,000 volumes for up to 600 students and 10,000 additional volumes for every additional 200 students is admittedly "based upon observation of the development of college libraries."1 Rather than actually setting standards, this document describes the less primitive existing practices and sanctions them with a "this-is-about-the-best-we-

1 American Library and Book Trade Annual, 1961 (New York, 1960), p. 121.
\end{abstract}

Mr. Massman is Director of Libraries and Miss Patterson is former Acquisitions Librarian at the University of South Dakota. can-hope-for" implication. Disregarding for the moment any greater range of course offerings at the larger institutions, one can only conclude that the undergraduate in a college of 600 students needs access to only half as much of the printed records of mankind as does the undergraduate at a college of 1,600 students, for this is what the Standards say-unless one assumes that those additional 50,000 volumes are all duplicate copies, which is hardly likely. The argument has always been that the student in the smaller school is not really deprived, because he has access to the better half-the "best" books. If that is the case, however, and if the argument is a valid one, then why should the library with 1,600 students be cluttered up with an extra 50,000 unnecessary "worse" books?

The "best book" theory as it has been applied to library development is an intrinsic contradiction which is completely inimical to the idea of presenting all points of view on significant social issues. Take two current problems, the war in Vietnam and the racial question. If the librarian selects only the "best books," can he really satisfy the need to represent all points of view? Will the librarian select the best books accord- 
ing to his own judgment, the judgment of reviewers, or the judgment of the users? Furthermore, in some cases the worst book on a controversial issue may be more enlightening than the best book, simply because the worst book (using the term "worst book" to identify the one which is obviously and unashamedly biased) may give special insights because it represents the distortions which can result from carrying a bias to its logical (or illogical) conclusion. In order to arrive at a sensible evaluation of an issue, the reader (and the society) must examine the values and deficiencies of the views supporting both the extreme left and the extreme right as well as those which are apparently more objective. Particularly in an academic library, the serious student must have access to all possible opinions, interpretations, ideas, and theories, whether these relate to current issues, the nature of matter, the theories of oral interpretation, or whatever.

An academic library's holdings can be determined only by the quantity and range of the materials being published which are relevant to the academic programs it is supporting, not by the traditional number-of-students criterion. Thus the library of any institution, regardless of size, with an undergraduate program in, for example, English history, must purchase all important books being published on English history which would be appropriate for undergraduate students. An institution supporting an M.A. or Ph.D. program must purchase a much greater wealth of materials. To say that a student in a college of 600 students needs only half as many books as the student in an institution of 1,600, as the Standards do, is to put ACRL's blessing on a textbook-reserve collection type of education for the student in the small college. The only relevant reality is the reality of the number and quality of books being produced.

Naturally the college with a larger number of students will need more duplicate copies, and it may also have a greater variety of programs. However, course for course and major for major there is no difference in the number of separate titles needed by any institution.

Obviously the above argument also leads to a questioning of the proposition that the book budget should be allocated according to a formula based on the number of faculty members and majors in a particular discipline. If a department of history says that it will not teach Asian or African or Greek or Black or constitutional or social history, and if it says further that those aspects of history are not worth teaching nor worth studying, then the library can and should exclude books in those areas which are specifically interdicted. However, unless specific areas of knowledge are intentionally excepted, ten students majoring in a subject area will need access to the same quantity of sources as one hundred students. At the same time certain areas of knowledge need to be considered in selection simply because the clientele will be interested. Many colleges do not offer courses in medicine or religion, for example, but these institutions will still need some books in these areas.

To arrive at a more objective and appropriate means of determining minimum standards, the writers carefully examined all the reviews printed during 1967 in seventy-one professional journals covering the disciplines usually found in undergraduate curricula. The initial list of journals was selected by the writers who then sought recommendations from the entire faculty. (See Appendix, p. 87.)

The major objective of the project was to determine the estimated annual cost to an academic library of keeping up with worthwhile current publications in the various disciplines. Retrospective purchasing was not considered, nor was purchasing of basic reference works such 
as encyclopedias, almanacs, irregular serials and annuals, popular best sellers, and fiction. Books reviewed were classified according to subject (more or less following broad Dewey classes) and appropriateness for an undergraduate library. Introductory textbooks and books which were of an ephemeral or elementary nature were omitted, even though they appeared in the reviewing media. Author, title, price, subject, source of publication, and journal in which reviewed were key punched for computer processing to determine the cost and number of books in each subject. An ideal budget for an individual library can be constructed according to the academic programs it is supporting, remembering that additional allowances must be made for categories of publications not included in this study.

In classifying reviewed books in a specific field as necessary for an undergraduate library, the presence of some institutional course work on the undergraduate level was assumed.

So far as classification by subject is concerned, it must be recognized that this sometimes was of necessity arbitrary. Interdisciplinary works were placed either in a broad general class or into the most likely subject covered. Therefore, when considering the number and cost of books in any one particular field, it must be remembered that many books in certain other areas may also be relevant. Obvious examples are sociology, psychology and education, fields whose literatures are interdependent. An institution with a drama department would certainly need works classified as technical theatre and would also need many of those classified in the literatures, including dramatic literature.

A total of 6,892 books which received favorable reviews were classified. After elimination of duplications, 5,771 separate titles were found to have been treated, 3,195 of which were of under- graduate significance. These fell into subject classifications as indicated in the Appendix, p. 87. An undergraduate library buying in all categories would acquire these 3,195 books, at a cost of $\$ 26,178.69$. It must be emphasized, of course, that these figures are based on book production as reviewed in seventyone journals. It does not include books which were not treated in these journals nor titles reviewed by these journals before or after 1967.

While the writers have not done a detailed study of the question, they estimate that the minimum expenditure for continuations would add at least another $\$ 3,250$. This would include new editions of encyclopedias on a regular basis, encyclopedia yearbooks, annuals such as "The Year's Work in ..." or "Advances in ....," and standard works as Books in Print, the World Almanac, Statistical Abstract, the MLA International Bibliography, etc. Furthermore, the list of books reviewed by the scholarly journals included only a small percentage of the titles which were on the annual best seller list. This means that the library will have to spend an additional sum for "popular" literature and current fiction, because the academic community needs these as well as the more scholarly works.

Based on an examination of reviews in seventy-one professional journals, then, the total minimum budget for one copy of those current titles (in this case current means the year 1967) which are appropriate to any and all libraries serving undergraduates is $\$ 29$,428.69. Obviously to arrive at a figure for 1968 or 1969, increases in book production and costs would have to be added to this basic figure. It is worth repeating that this figure does not make any allowance for any retrospective deficiencies, periodicals, newspapers, reprints, audiovisual materials, government documents, "popular works," replacement items, duplicate copies, or 
materials which are mainly of local interest. Budgetary provision for these items must be in addition to the basic sum of $\$ 29,428.69$. If the college does not offer courses in journalism, for example, the total might be reduced by \$303.22. If the institution has no courses in agriculture or home economics, the budget might be reduced another $\$ 78.80$, and so on. Once the curriculum is established, however, the academic library can readily determine how much money it will need as a minimum budget. A truly quality collection will need far more than that.

No doubt many readers will raise the specter of local differences with regard to some aspects of the proposal under consideration. Because of our local situation, because of the peculiar interests of our students and our faculty and our community, so the argument goes, our collection needs many special kinds of materials and does not need those which other libraries buy. This argument has been repeated so often that everyone accepts it without considering what it really means. Is there any college in the United States which does not need substantial coverage on such questions as the war in Vietnam, racial problems, student unrest, Shakespeare, the Civil War, Russian history? If there is, is that institution really worthy of being called a college? Must or should the library resources supporting a course in American history really differ radically between colleges in the Midwest and the deep South? If they really differ substantially, is this not likely a result of biased selection on the part of the faculty or the librarian? Is not the content of American history the same whether taught in South Dakota or Germany? Both students and faculty members across the country are far more homogeneous now because of the mobility of people in our society than they were thirty years ago, so does the old cliche still apply-if it ever did?

Local differences, however, have meaning in one respect. Obviously the University of South Dakota will buy books, pamphlets, and periodicals which are relevant to the concerns of South Dakota and the region, and some of these would be of little immediate interest to students and faculty members in Alaska. However, the point to be made is that this is an added cost factor, not a substitution for materials which deal with national and world issues.

The standards outlined in the ACRL "Standards for College Libraries" are no standards at all. Naturally the list of journals chosen for examination as well as the judgment of the reviews (and the readers of the reviews) can readily be questioned. Nevertheless, the basic budget of $\$ 29,428.69$ is at least suggestive because it reflects the only reality upon which standards can be basedbook production and the existence of specific courses in the curriculum.

If ACRL, exercising some authority as a sanctioning or accrediting agency, were to establish adequate minimum standards and then were to insist that a library which fails to meet those standards is incapable of supporting an effective undergraduate program, and if standards for current purchasing were based on course offerings and book production, as this article suggests, the inequities and deficiencies of academic library collections could to an extent be decreased. Surely this is a goal worth working toward. And even if ACRL's efforts had no impact on improving library resources, ACRL could take pride in refusing to sanction mediocrity. 


\section{APPENDIX}

Reviewing Journals Consulted (1967)

Accounting Review

American Anthropologist

American Artist

American Economic Review

American Historical Review

American Journal of Archeology

American Journal of Physics

American Journal of Psychology

American Literature

American Musicological Society Journal

American Political Science Review

American Scientist

American Sociological Review

Analytical Chemistry

Animal Behavior

Annals

Art in America

Arts Magazine

Astronomical Society of the Pacific

Classical Journal

Classical World

College \& Research Libraries

Comparative Literature

Dance Magazine

Economic Journal

Educational Leadership

English Historical Review

Ethics

Geographical Review

Germanic Review

Hibbert Journal

Hispanic American Historical Review

Hispanic Review

Human Biology
Isis

Journal of American History

Journal of Chemical Education

Journal of English and Germanic Philology

Journal of Geology

JOHPER

Journal of Higher Education

Journal of Marketing

Journal of Political Economy

Journal of Religion

Journal of the Am. Chem. Soc.

JAMA

Journalism Quarterly

Library Quarterly

Mathematical Gazette

Mind

Modern Language Notes

Music Library Association Notes

NASSP Bulletin

Personnel and Guidance Journal

Philosophical Quarterly

Philosophical Review

Physics Review

Political Studies

Public Administration Review

Quarterly Journal of Speech

Quarterly Journal of Biology

Review of English Studies

Review of Metaphysics

Romance Philology

Rural Sociology

Science

Scripta Mathematica

Sky and Telescope

Slavic Review

Teachers College Record

Torrey Botanical Club Bulletin

Estimated Annual Cost, to an Academic Library, of Maintaining Current Publications

\begin{tabular}{|c|c|c|}
\hline Subject & Number of Titles & Cost \\
\hline Agriculture & 8 & 44.35 \\
\hline Anthropology and Archeology & 88 & 951.58 \\
\hline Architecture & 10 & 131.45 \\
\hline Art & 50 & 693.29 \\
\hline Astronomy & 28 & 273.30 \\
\hline Biology & 113 & $1,502.85$ \\
\hline Botany & 32 & 395.25 \\
\hline Business & 56 & 419.29 \\
\hline Chemistry & 98 & $1,273.69$ \\
\hline Economics & 138 & 916.18 \\
\hline Education & 126 & 727.03 \\
\hline Engineering & 22 & 250.61 \\
\hline Geography & 25 & 246.82 \\
\hline
\end{tabular}




\begin{tabular}{|c|c|c|}
\hline Subject & Number of Titles & Cost \\
\hline Geology & 22 & 252.45 \\
\hline Graphic Arts & 3 & 30.00 \\
\hline \multicolumn{3}{|l|}{ History } \\
\hline African & 67 & 499.68 \\
\hline American & 229 & $1,684.59$ \\
\hline Ancient & 40 & 310.66 \\
\hline Asian & 105 & 740.03 \\
\hline English & 80 & 582.21 \\
\hline European & 140 & $1,039.75$ \\
\hline General History and Exploration & 42 & 380.87 \\
\hline Latin American & 69 & 508.73 \\
\hline Home Economics & 3 & 34.45 \\
\hline Journalism & 41 & 303.22 \\
\hline Language and Literature (General Works) & 56 & 389.77 \\
\hline American & 91 & 611.46 \\
\hline English & 97 & 662.12 \\
\hline French & 11 & 76.07 \\
\hline German & 12 & 95.95 \\
\hline Greek & 23 & 120.02 \\
\hline Italian & 4 & 37.73 \\
\hline Latin & 13 & 72.85 \\
\hline Russian and Slavic & 9 & 62.70 \\
\hline Spanish and Relations & 15 & 115.74 \\
\hline Law & 15 & 114.02 \\
\hline Library Science & 51 & 470.53 \\
\hline Mathematics & 57 & 505.36 \\
\hline Medicine & 48 & 419.58 \\
\hline Music & 42 & 367.55 \\
\hline Paleontology & 7 & 59.48 \\
\hline Philosophy & 137 & 994.04 \\
\hline Photography & 4 & 35.40 \\
\hline Physical Education, Dance and Recreation & 49 & 285.77 \\
\hline Physics & 75 & 830.19 \\
\hline Political Science and Government, Theoretical and U.S. & 119 & 694.63 \\
\hline \multirow{2}{*}{\multicolumn{3}{|c|}{ Political Science and Government, Foreign; Internation- }} \\
\hline & 129 & 832.17 \\
\hline Psychology & 76 & 597.28 \\
\hline Public Relations and Public Administration & 10 & 84.60 \\
\hline Religion & 8 & 22.22 \\
\hline Bible & 1 & 16.95 \\
\hline Christian & 23 & 555.98 \\
\hline Theology & 17 & 79.68 \\
\hline Judaic & 5 & 33.72 \\
\hline Social Work & 12 & 79.20 \\
\hline Sociology & 152 & 959.77 \\
\hline Speech & 25 & 135.24 \\
\hline Statistics & 10 & 86.23 \\
\hline Science in General & 76 & 682.67 \\
\hline Theatre & 42 & 291.04 \\
\hline \multirow[t]{2}{*}{ Zoology } & 41 & 508.74 \\
\hline & 3,195 & $\$ 26,178.69$ \\
\hline
\end{tabular}

Additional allocations must be considered in some instances due to apparent biases in certain reviewing journals concerning foreign publications and foreign language materials. 